\title{
Effects of phosphine fumigation on the quality of soybean seeds ${ }^{1}$
}

\author{
Francisco Carlos Krzyzanowski²*, Irineu Lorini², \\ José de Barros França-Neto², Ademir Assis Henning ${ }^{2}$
}

\begin{abstract}
Fumigation is a technique employed to eliminate insect pests in stored seeds by using gas. The aim of the experiment was to evaluate the effect of the gas phosphine on germination and on vigor (accelerated aging and seedling length) of soybean seeds. Soybean seeds of two cultivars with two vigor levels were used. Each treatment was replicated four times and each experimental unit consisted of two kilograms of seeds, which were placed in individual $1 \mathrm{~m}^{3}$ gas-tight capacity chambers with phosphine. The concentrations used were $1.0 ; 2.0$ and $3.0 \mathrm{~g} \mathrm{PH}_{3} \mathrm{~m}^{-3}$, achieved by applying $3.0 ; 6.0 \mathrm{and} 9.0 \mathrm{~g}$ of Fertox ${ }^{\circledR}$ commercial formulation. During seven days, the phosphine gas concentration within each chamber was monitored using the Silochek ${ }^{\circledR}$ gas meter. After this period, the chambers were opened, the seeds were removed and the quality analyses were performed. Throughout the experiment, $\mathrm{PH}_{3}$ concentrations in the chambers remained at the concentrations required for the elimination of all life stages of insect pests of stored seed. Even in the lowest dosage, the gas concentration remained above $400 \mathrm{ppm}$ that is considered the minimum concentration for eliminating insect pests. No detrimental effects were detected on the physiological quality of the fumigated seeds.
\end{abstract}

Index terms: storage, pest control, germination, vigor.

\section{Efeito do expurgo com fosfina sobre a qualidade de sementes de soja}

RESUMO - O expurgo é uma técnica empregada para eliminar pragas infestantes em sementes armazenadas mediante uso de gás. O objetivo do experimento foi avaliar o efeito da fosfina na germinação e no vigor (envelhecimento acelerado e comprimento de plântula) da semente de soja. Foram usadas sementes de soja de duas cultivares com dois níveis de vigor. Cada unidade experimental composta por dois quilogramas de sementes de cada repetição foi colocada em câmaras individuais

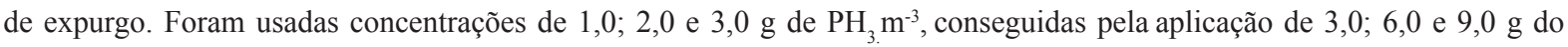
produto comercial Fertox ${ }^{\circledR}$. Diariamente, durante sete dias, foi monitorada a concentração do gás fosfina no interior de cada câmara através do medidor Silochek ${ }^{\circledR}$. Após este período, as câmaras foram abertas, retiradas as sementes e realizadas as análises de qualidade. As concentrações de fosfina se mantiveram nas concentrações necessárias para a eliminação de todas as fases das pragas de sementes armazenadas. Mesmo a dose mais baixa manteve a concentração superior aos 400 ppm que é a referência técnica de concentração mínima para eliminar os insetos praga. Não foram detectados efeitos adversos dos tratamentos na qualidade fisiológica das sementes de soja.

Termos para indexação: armazenamento, controle de pragas, germinação, vigor.

\section{Introduction}

The evolution of soybean cultivars and population management of grain production crops have been demanding the supply of soybean seeds of high physical, physiological, genetical and sanitary quality. The maintenance of quality during storage, in addition to the physiological and sanitary parameters, requires also the management of pests.

There are several storage pests that occur in soybean seeds, and among them the following stand out most often: Lasioderma serricorne, Cryptolestes ferrugineus, Oryzaephilus surinamensis, Ephestia elutella and Ephestia cautella, Sitophilus oryzae, Rhyzopertha dominica, Tribolium castaneum, Liposcelis bostrychophila, Ahasverus advena and Lophocateres pusillus (Krzyzanowski et al., 2010; França-Neto et al., 2011). In Brazil, the highest incidences of infestation have been reported for $S$. oryzae, followed by Ephestia spp, $R$. dominica and L. serricorne (França-Neto et al., 2011).

${ }^{1}$ Submitted on $05 / 30 / 2012$. Accepted for publication on 10/29/2012.

${ }^{2}$ Tecnologia de Sementes da Embrapa Soja, Caixa Postal 231, 86001-970 - Londrina, PR, Brasil.

*Corresponding author $<$ francisco.krzyzanowski@embrapa.br $>$ 
Due to the occurrence of these pests, in particular Lasioderma serricorne, on grains and soybean seeds, fumigation has been adopted as a routine practice during soybean storage (França-Neto et al., 2010; Lorini et al., 2010).

Fumigation is a technique used to eliminate pests in stored seeds and grains by using gas. It should be performed whenever there is infestation in a seed lot, silo or warehouse. This process can be accomplished in many different storage facilities, as long as they provide the perfect sealing of the site to be fumigated and the safety standards for the products in use. The gas released or introduced into the grain mass must remain in this environment at concentrations lethal to the pest. Therefore, any air outlet or intake must always be sealed with appropriate materials, such as a fumigation tarp (Lorini, 2008).

The gas distribution should be uniform in all parts of the mass of grains or seeds to be treated, thus controlling all pests in their different life stages (Lorini et al., 2002). The release rate of the phosphine gas $\left(\mathrm{PH}_{3}\right)$ coming from the fumigation pellets will determine the time required for total mortality of the pests and efficiency of the process (Lorini et al., 2011).

Phosphine is a general biocide, also known as phosphorus hydride, aluminum phosphide, and trimagnesium diphosphide, and is a highly toxic gas, which is released in the presence of humidity.

Although it has been used on seeds of other species for many years, only recently it started to be used on soybean seeds, due to the presence of pests during storage. Since phosphine is a biocide, there are questions about its effect on the physiological quality of the seed.

The objective of this study was to evaluate the effect of phosphine on germination and vigor, factors affecting the quality of the soybean seed.

\section{Material and Methods}

Seeds of soybean with two levels of vigor determined by the tetrazolium test, from cultivars Embrapa 48 (93\% and $82 \%$ ) and CD 202 (69\% and 62\%) were used in this study. Each experimental unit consisted of two kilograms of seeds that were placed in individual fumigation chambers, made of plastic tarp impermeable to phosphine gas, with $1.0 \mathrm{~m}^{3}$ capacity. Concentrations of $1.0 ; 2.0$ and $3.0 \mathrm{~g}$ of $\mathrm{PH}_{3} \mathrm{~m}^{-3}$ achieved by the application of $3.0 ; 6.0$ and $9.0 \mathrm{~g}$ of Fertox ${ }^{\circledR}$ commercial product were used. During seven days the concentration of phosphine gas within each chamber was monitored by means of the Silochek ${ }^{\circledR}$ meter, which measures the concentration in ppm of phosphine gas after a certain period of time from the release of the gas by the aluminum phosphide tablets.

After this period, the chambers were opened, the seeds were removed and the quality analyses were conducted, by germination (Brasil, 2009), seedling length, hypocotyl length and accelerated aging tests (Krzyzanowski et al., 1999).

A completely randomized experimental design was used, the treatments consisting of three fumigation schemes (1.0; 2.0 and $3.0 \mathrm{~g}$ of $\mathrm{PH}_{3} \mathrm{~m}^{-3}$ ), in addition to a control treatment without phosphine application. Each treatment was evaluated in seeds of each cultivar within each level of vigor (low and high) with four replications, each replication being composed of four sub-samples of 50 seeds each, for all variables. The data were interpreted statistically by variance analysis. For all statistical analyses, the software SASM - Agri was used (Canteri et al., 2001).

\section{Results and Discussion}

The phosphine concentration in the chamber was maintained throughout the experimental period, allowing the exposure of the seeds to the gas in the concentrations determined. Even at the lowest dose, it was maintained for 168 hours at a concentration higher than 400 ppm (Figures 1 and 2), which is the technical reference of minimum concentration for the control of all stages of insect pests of stored seeds (Daglish et al., 2002).

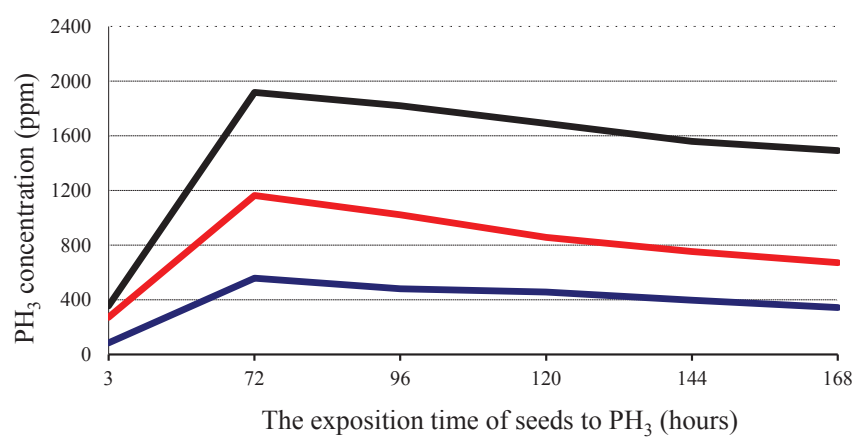

Delivered $1 \mathrm{~g}$ of $\mathrm{PH} 3 / \mathrm{m} 3 \longrightarrow$ Delivered $2 \mathrm{~g}$ of $\mathrm{PH} 3 / \mathrm{m} 3 \longrightarrow$ Delivered $3 \mathrm{~g}$ of $\mathrm{PH} 3 / \mathrm{m} 3$

Figure 1. Monitoring of the concentration of phosphine $\left(\mathrm{PH}_{3}\right)$ during the fumigation process of soybean seeds of the cultivar Embrapa 48.

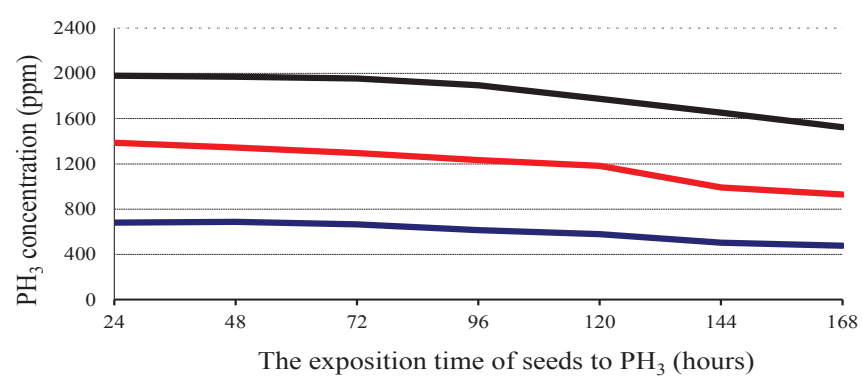

Delivered $1 \mathrm{~g}$ of $\mathrm{PH} 3 / \mathrm{m} 3 \longrightarrow$ Delivered $2 \mathrm{~g}$ of $\mathrm{PH} 3 / \mathrm{m} 3 \longrightarrow$ Delivered $3 \mathrm{~g}$ of $\mathrm{PH} 3 / \mathrm{m} 3$

Figure 2. Monitoring of the concentration of phosphine $\left(\mathrm{PH}_{3}\right)$ during the fumigation process of soybean seeds of the cultivar CD 202. 
For the results of the seed physiological quality assessment, the three dosages of phosphine applied, i.e., $1.0 ; 2.0$ and 3.0 g. $\mathrm{m}^{-3}$, presented no significant differences compared to the control (Tables 1 and 2). The application of phosphine did not affect seed germination and vigor. Seedling and hypocotyl length tests, which indicate the occurrence of possible phytotoxicity caused by the product, did not detect any effect on the levels of phosphine used in the fumigation treatments evaluated in both cultivars and both levels of vigor assessed. Andrade and Nascimento (1984), working with corn and sorghum seeds, and Rocha-Junior and Usberti (2007), working with seeds of wheat cultivars, did not observe the immediate effects of the fumigation with phosphine on the physiological performance of the seed.

Table 1. Effect of the fumigation process with three concentrations of phosphine on germination (G), accelerated aging (AA), seedling length (SL) and hypocotyls length (HL) of soybean seeds of cultivar Embrapa 48 with two levels of vigor.

\begin{tabular}{|c|c|c|c|c|}
\hline \multirow{3}{*}{$\mathrm{PH}_{3}\left(\mathrm{~g} \cdot \mathrm{m}^{3}\right)$} & \multicolumn{4}{|c|}{ Vigor TZ - $82 \%$} \\
\hline & $\mathrm{G}$ & AA & SL & HL \\
\hline & \multicolumn{2}{|c|}{------------------------"\%"-------------------- } & \multicolumn{2}{|c|}{ 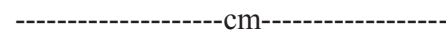 } \\
\hline Control & $77^{*}$ & $72 *$ & $29.40 *$ & $9.32 *$ \\
\hline 1 Pellet $\left(1\right.$ g.m $\left.\mathrm{m}^{-3}\right)$ & 75 & 69 & 28.14 & 9.34 \\
\hline 2 Pellets $\left(2\right.$ g.m $\left.\mathrm{m}^{-3}\right)$ & 73 & 68 & 27.08 & 9.02 \\
\hline 3 Pellets $\left(3\right.$ g.m $\left.\mathrm{m}^{-3}\right)$ & 77 & 68 & 28.64 & 9.80 \\
\hline F Test & $1.95 \mathrm{~ns}$ & $1.03 \mathrm{~ns}$ & $0.76 \mathrm{~ns}$ & $0.62 \mathrm{~ns}$ \\
\hline Variation Coefficient $(\%)$ & 4.0 & 4.0 & 7.84 & 8.67 \\
\hline \multirow{3}{*}{$\mathrm{PH}_{3}\left(\mathrm{~g} \cdot \mathrm{m}^{3}\right)$} & \multicolumn{4}{|c|}{ Vigor TZ - 93\% } \\
\hline & G & AA & SL & HL \\
\hline & \multicolumn{2}{|c|}{----------------------------\%"0-------------------- } & \multicolumn{2}{|c|}{----------------------cm------------------ } \\
\hline Control & $84 *$ & $84 *$ & $28.55^{*}$ & $9.13^{*}$ \\
\hline 1 Pellet $\left(1\right.$ g.m $\left.\mathrm{m}^{-3}\right)$ & 87 & 85 & 29.88 & 9.75 \\
\hline 2 Pellets $\left(2\right.$ g.m $\left.\mathrm{m}^{-3}\right)$ & 88 & 85 & 29.79 & 9.68 \\
\hline 3 Pellets $\left(3\right.$ g.m $\left.\mathrm{m}^{-3}\right)$ & 87 & 84 & 29.29 & 9.61 \\
\hline F Test & $1.60 \mathrm{~ns}$ & $0.98 \mathrm{~ns}$ & $0.39 \mathrm{~ns}$ & $0.22 \mathrm{~ns}$ \\
\hline Variation Coefficient (\%) & 2.69 & 1.72 & 6.57 & 12.41 \\
\hline
\end{tabular}

* Means within the columns, in the same level of vigor, do not differ from each other by the F test $(\mathrm{p} \leq 0.05)$.

Table 2. Effect of the fumigation process with three concentrations of phosphine on germination (G), accelerated aging (AA), seedling length (SL) and hypocotyls length (HL) of soybean seeds of cultivar CD 202 with two levels of vigor.

\begin{tabular}{|c|c|c|c|c|}
\hline \multirow{3}{*}{$\mathrm{PH}_{3}\left(\mathrm{~g} \cdot \mathrm{m}^{3}\right)$} & \multicolumn{4}{|c|}{ TZ Vigor - $62 \%$} \\
\hline & G & AA & SL & HL \\
\hline & \multicolumn{2}{|c|}{-------------------\%\%-------------------- } & \multicolumn{2}{|c|}{------------------------\%"-------------------- } \\
\hline Control & $84 *$ & $72 *$ & $24.93 *$ & $7.75^{*}$ \\
\hline 1 Pellet $\left(1\right.$ g.m $\left.{ }^{-3}\right)$ & 84 & 74 & 23.23 & 7.57 \\
\hline 2 Pellets $\left(2\right.$ g.m $\left.{ }^{-3}\right)$ & 83 & 72 & 23.13 & 7.51 \\
\hline 3 Pellets $\left(3\right.$ g.m $\left.\mathrm{m}^{-3}\right)$ & 82 & 70 & 24.16 & 7.73 \\
\hline F Test & $0.68 \mathrm{~ns}$ & $1.41 \mathrm{~ns}$ & $1.01 \mathrm{~ns}$ & $0.08 \mathrm{~ns}$ \\
\hline Variation Coefficient (\%) & 2.67 & 7.08 & 7.07 & 10.21 \\
\hline \multirow{3}{*}{$\mathrm{PH}_{3}\left(\mathrm{~g} \cdot \mathrm{m}^{3}\right)$} & \multicolumn{4}{|c|}{ TZ Vigor - $69 \%$} \\
\hline & $\mathrm{G}$ & AA & SL & HL \\
\hline & \multicolumn{2}{|c|}{-------------------\%\%-------------------- } & \multicolumn{2}{|c|}{ 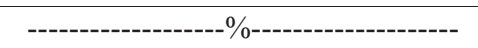 } \\
\hline Control & $87 *$ & $68 *$ & $24.89^{*}$ & $7.75^{*}$ \\
\hline 1 Pellet $\left(1\right.$ g.m $\left.{ }^{-3}\right)$ & 87 & 69 & 26.15 & 8.54 \\
\hline 2 Pellets $\left(2\right.$ g.m $\left.\mathrm{m}^{-3}\right)$ & 86 & 71 & 26.67 & 8.40 \\
\hline 3 Pellets $\left(3 \mathrm{~g} \cdot \mathrm{m}^{-3}\right)$ & 86 & 70 & 25.95 & 8.45 \\
\hline F Test & $0.52 \mathrm{~ns}$ & $0.54 \mathrm{~ns}$ & $0.82 \mathrm{~ns}$ & $1.80 \mathrm{~ns}$ \\
\hline Variation Coefficient (\%) & 2.39 & 4.96 & 6.35 & 6.47 \\
\hline
\end{tabular}

*Means within the columns, in the same level of vigor, do not differ from each other by the $\mathrm{F}$ test $(\mathrm{p} \leq 0.05)$. 


\section{Conclusion}

The fumigation with phosphine, within the dosages evaluated, can be used without injury to the physiological quality of the soybean seed.

\section{References}

ANDRADE, R.V.; NASCIMENTO, T.F. Efeito do expurgo com fosfina (gastoxin) sobre a qualidade fisiológica de sementes de milho e sorgo. Revista Brasileira de Sementes, v.6, n.2, p.9-16, 1984. http://www.abrates.org.br/ revista/artigos/1984/v6n2/artigo01.pdf

BRASIL. Ministério da Agricultura, Pecuária e Abastecimento. Regras para análise de sementes. Ministério da Agricultura, Pecuária e Abastecimento. Secretaria de Defesa Agropecuária. Brasília, DF: MAPA/ACS, 2009, 395p. http://www.bs.cca.ufsc.br/publicacoes/regras\%20analise $\% 20$ sementes.pdf

CANTERI, M.G.; ALTHAUS, R.A.; VIRGENS FILHO, J.S.; GIGLIOTI, E.A.; GODOY, C.V. SASM - Agri: Sistema para análise e separação de médias em experimentos agrícolas pelos métodos Scott - Knott, Tukey e Duncan. Revista Brasileira de Agrocomputação, v.1, n.2, p.18-24, 2001. http://www. agrocomputacao.deinfo.uepg.br/dezembro_2001/arquivos/rbac_artigo_03.pdf

DAGLISH, G.J.; COLLINS, P.J.; PAVIC, H.; KOPITTKE, R. Effects of time and concentration on mortality of phosphine-resistant Sitophilus oryzae (L) fumigated with phosphine. Pest Management Science, v.58, n.10, p.1015-1021, 2002.

FRANÇA-NETO, J.B.; LORINI, I.; KRZYZANOWSKI, F.C.; HENNING, A.A.; MALLMANN, C.A. Ocorrência de contaminantes em grãos e sementes de soja armazenados em diversas regiões brasileiras. In: CONFERÊNCIA BRASILEIRA DE PÓS-COLHEITA, 5., 2012, Foz do Iguaçu. Anais... Londrina: ABRAPOS, 2010. p.278-280.
FRANÇA-NETO, J.B.; LORINI, I.; KRZYZANOWSKI, F.C.; HENNING, A.A.; MALLMANN, C.A. Ocorrência de contaminantes em sementes e grãos de soja armazenados em diferentes regiões brasileiras no período de 20082010. In: REUNIÃO DE PESQUISA DE SOJA DA REGIÃO CENTRAL DO BRASIL, 32., 2011, São Pedro, SP. Resumos expandidos... Londrina: Embrapa Soja, 2011.p. 342-344

KRZYZANOWSKI, F.C.; VIEIRA, R.D.; FRANÇA-NETO, J.B. Vigor de sementes: conceitos e testes. Londrina: ABRATES, 1999. 219p.

KRZYZANOWSKI, F.C.; LORINI, I.; FRANÇA-NETO, J.B.; HENNING, A.A. Effect of phosphine fumigation on the physiological quality of soybean seed. $29^{\text {th }}$ ISTA Congress - Seed Symposium, Cologne, 16 - 18 June 2010. p.62.

LORINI, I.; MIIKE, L.H.; SCUSSEL, V.M. Armazenagem de grãos. Campinas: IBG, 2002. 983p.

LORINI, I. Manejo integrado de pragas de grãos de cereais armazenados. Passo Fundo: Embrapa Trigo, 2008. 72p.

LORINI, I.; FERRI, G.C.; FREITAS, A.D.M.; ROSSATO, C. Desenvolvimento de Lasioderma serricorne (F.) (Coleoptera: Anobiidae) em grãos de soja armazenada. In: CONFERÊNCIA BRASILEIRA DE PÓS-COLHEITA, 5., 2010 Foz do Iguaçu. Anais... Londrina: ABRAPOS, 2010. p.363-366.

LORINI, I.; KRZYZANOWSKI, F.C.; FRANÇA-NETO, J.B.; HENNING, A.A. Monitoramento da liberação do gás PH3 por pastilhas de fosfina usadas para expurgo de sementes. Informativo Abrates, v.21, n.3, p.57-60, 2011. http:// www.abrates.org.br/portal/images/stories/informativos/v21n3/artigo07.pdf

ROCHA-JUNIOR, L.S.; USBERTI, R. Qualidade física e fisiológica de sementes de trigo expurgadas com fosfina durante o armazenamento. Revista Brasileira de Sementes, v.29, n.1, p.45-51, 2007. http://www.scielo.br/pdf/ rbs/v29n1/07.pdf 